Eastern Illinois University

The Keep

Faculty Research \& Creative Activity

Biological Sciences

January 2010

\title{
DNA Double-Strand Breakage as an Endpoint to Examine Metal and Radionuclide Exposure Effects to Water Snakes on a Nuclear Industrial Site
}

\author{
Stephanie M. Murray \\ Rutgers University \\ Karen F. Gaines \\ Eastern Illinois University, kfgaines@eiu.edu \\ James M. Novak \\ Eastern Illinois University \\ Michael Gochfeld \\ Environmental and Occupational Health Sciences Institute \\ Joanna Burger \\ Rutgers University
}

Follow this and additional works at: http://thekeep.eiu.edu/bio_fac

Part of the Biology Commons

\section{Recommended Citation}

Murray, Stephanie M.; Gaines, Karen F.; Novak, James M.; Gochfeld, Michael; and Burger, Joanna, "DNA Double-Strand Breakage as an Endpoint to Examine Metal and Radionuclide Exposure Effects to Water Snakes on a Nuclear Industrial Site" (2010). Faculty Research \& Creative Activity. 35.

http://thekeep.eiu.edu/bio_fac/35

This Article is brought to you for free and open access by the Biological Sciences at The Keep. It has been accepted for inclusion in Faculty Research \& Creative Activity by an authorized administrator of The Keep. For more information, please contact tabruns@eiu.edu. 
This article was downloaded by: [Gaines, K.]

On: 10 April 2010

Access details: Access Details: [subscription number 921135816]

Publisher Taylor \& Francis

Informa Ltd Registered in England and Wales Registered Number: 1072954 Registered office: Mortimer House, 3741 Mortimer Street, London W1T 3JH, UK

Human and

Ecological

Risk

Assessment

Astimatiman

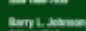

네에

tonstions

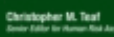

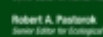

mance

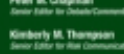

() vitatinach
Human and Ecological Risk Assessment: An International Journal

Publication details, including instructions for authors and subscription information:

http://www.informaworld.com/smpp/title content=t713400879

\section{DNA Double-Strand Breakage as an Endpoint to Examine Metal and} Radionuclide Exposure Effects to Water Snakes on a Nuclear Industrial Site

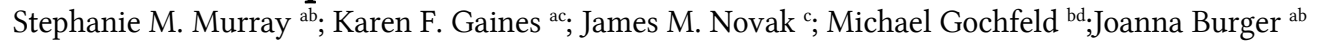

${ }^{\text {a }}$ Division of Life Sciences, Rutgers University, Piscataway, NJ, USA ${ }^{\mathrm{b}}$ Consortium for Risk Evaluation with Stakeholder Participation, Environmental and Occupational Health Sciences Institute, Piscataway, NJ, USA ${ }^{c}$ Department of Biological Sciences, Eastern Illinois University, Charleston, IL, USA ${ }^{d}$

Environmental and Community Medicine, UMDNJ-Robert Wood Johnson Medical School, Piscataway, NJ, USA

Online publication date: 09 April 2010

To cite this Article Murray, Stephanie M., Gaines, Karen F. , Novak, James M. , Gochfeld, Michael andBurger, Joanna(2010) 'DNA Double-Strand Breakage as an Endpoint to Examine Metal and Radionuclide Exposure Effects to Water Snakes on a Nuclear Industrial Site', Human and Ecological Risk Assessment: An International Journal, $16: 2,282$ $-300$

To link to this Article: DOI: $10.1080 / 10807031003670337$

URL: http://dx.doi.org/10.1080/10807031003670337

\section{PLEASE SCROLL DOWN FOR ARTICLE}

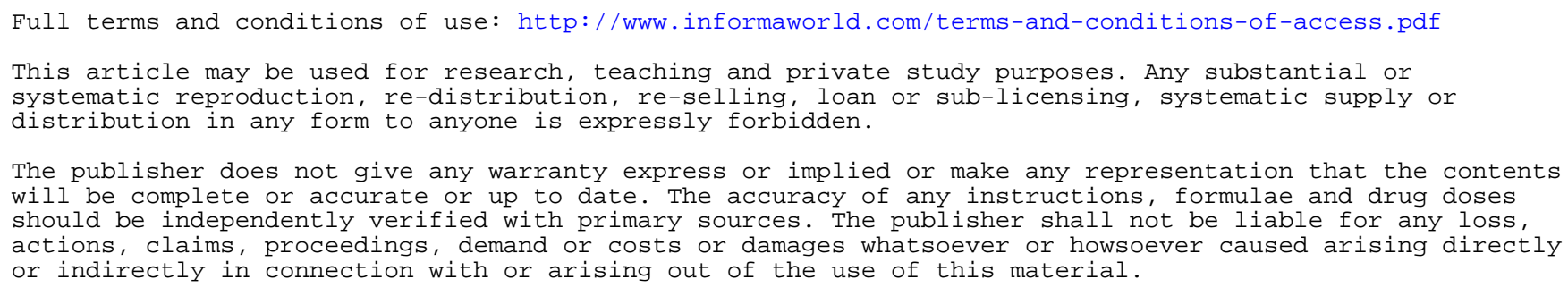




\title{
DNA Double-Strand Breakage as an Endpoint to Examine Metal and Radionuclide Exposure Effects to Water Snakes on a Nuclear Industrial Site
}

\author{
Stephanie M. Murray, ${ }^{1,2}$ Karen F. Gaines, ${ }^{2,3}$ James M. Novak, ${ }^{3}$ Michael Gochfeld, ${ }^{2,4}$ \\ and Joanna Burger ${ }^{1,2}$ \\ ${ }^{1}$ Division of Life Sciences, Rutgers University, Piscataway, NJ, USA; ${ }^{2}$ Consortium for \\ Risk Evaluation with Stakeholder Participation, Environmental and Occupational \\ Health Sciences Institute, Piscataway, NJ, USA; ${ }^{3}$ Department of Biological Sciences, \\ Eastern Illinois University, Charleston, IL, USA; ${ }^{4}$ Environmental and Community \\ Medicine, UMDNJ-Robert Wood Johnson Medical School,, Piscataway, NJ, USA
}

\begin{abstract}
This study examined metal levels (especially $\mathrm{U}$ and $\mathrm{Ni}$ ) in the tail tissues of water snakes from contaminated (Tim's Branch) and reference areas on the Department of Energy's Savannah River Site (SRS). Home ranges of snakes were quantified to determine the ratio of the habitat that they use in relation to the contaminated areas to better estimate exposure Compared to conventional methods that do not. The exposure assessment indicated that water snakes in the contaminated areas could expect $U$ exposure at 3-4 orders of magnitude greater than the Agency for Toxic Substances and Disease Registry's Minimum Risk Level (MRL) from ingestion of amphibians and fish. $\mathrm{Ni}$ and $\mathrm{U}$, in addition to $\mathrm{Se}, \mathrm{Mn}$, and $\mathrm{Cu}$, were related to increased DNA double-strand breakage (DDSB) in water snakes. We report burdens for each metal individually, but the results of the DDSB indicated that these metals did not behave independently, but as a suite. If we did not have a secondary endpoint (DDSB), we might have assumed from the exposure predictions and tissue burden analyses that $U$ was the sole metal of concern to water snakes in Tim's Branch. These data also imply that these toxicants do not biomagnify at the spatial and temporal scale of this study.
\end{abstract}

Key Words: DNA double-strand breaks, exposure, uranium, Nerodia, nickel, water snakes.

Received 27 February 2009; revised manuscript accepted 21 March 2009.

Address correspondence to Karen F. Gaines, Ph.D., Eastern Illinois University, Department of Biological Sciences, 600 Lincoln Ave., Charleston, IL 61920-3099, USA. E-mail: kfgaines@eiu.edu 


\section{$\mathrm{Ni}$ and $\mathrm{U}$ in Water Snakes}

\section{INTRODUCTION}

No risk to a biological system exists unless there is the potential for exposure, and accumulation that might cause adverse effects (Sparling et al. 2000). Risk assessment must be preceded by an understanding of the behavior of the toxicant in a particular environment. There are only a limited number of studies examining bioaccumulation and the effects of metal and radionuclide contamination in snakes and subsequently how these toxicants may pose adverse effects (Campbell and Campbell 2001). Snakes are model receptor species for risk assessment in relation to the extent of contamination through an ecosystem via trophic transfer because of their life history and ability to bioaccumulate contaminants (Hopkins 2000). For example, studies have found correlations between blood and tail snips with tissue burdens for metals that were elevated at their sample site (Hopkins et al. 2001).

On the U.S. Department of Energy's (USDOE) Savannah River Site (SRS), the effects of contamination can still be detected in the environment from disturbances over the past 50 years from production facilities. Specifically, the biogeochemical cycling of heavy metals in a riparian ecosystem (Steed's Pond-Tim's Branch) contaminated with $\mathrm{U}, \mathrm{Cr}, \mathrm{Cu}, \mathrm{Al}, \mathrm{Mn}$, and particularly $\mathrm{Ni}$, were investigated in relation to their bioavailability to carnivorous aquatic snakes: the banded water snake (Nerodia fasciata), the brown water snake (Nerodia taxispilota), and the cottonmouth (Agkistrodon piscivorous) - which is not taxonomically considered a water snake, but occupies a similar ecological niche.

Presently, predicting risk to reptile populations is difficult because of insufficient data for the estimation of individual responses as a function of heavy metal concentrations (Hopkins 2000). However, numerous effects of heavy metals on small mammal DNA have been summarized by Hartwig (1995), where specific metals such as Ni, Cr, As, and Cd have been associated with DNA damaging effects. Similarly, Lamb et al. (1991) illustrated DNA damage associated with gamma and strong beta radiation exposure from radiocesium and radiostrontium in slider turtles (Trachemys spp.). Because reptiles exhibit DNA damage as a result of a toxicant stress, the use of this metric as an endpoint of ecological risk in reptiles may be ideal in some systems (Lamb et al. 1991). Since reptiles have nucleated erythrocytes, a small blood sample can be used to quantify DNA double-strand breakage (DDSB) thus providing a non-destructive endpoint in modeling ecological risk.

This research examines the relationship between metal tissue concentration of water snakes to DDSB with a specific focus on U and Ni. Both the USDOE and the U.S. Environmental Protection Agency (USEPA) are focused on these contaminants in the efforts to remediate the disturbed watershed associated with Tim's Branch (Punshon et al. 2003b). DDSB was chosen as a specific endpoint because of the documented relationship of this metric to these and other toxicants. Specifically, $\mathrm{Ni}$ interferes with the repair of UV (ultra-violet) and X-ray-induced DNA damage during the recognition/incision and polymerization/ligation stages (Christie 1989). In fact, Christie (1989) has shown that DNA damage that has been affected by X-rays, and ultraviolet light may be more susceptible to cellular processing in the presence of Ni. Further, U gamma-emitting daughter products present in the Steed's Pond-Tim's Branch corridor may potentially contribute to DNA damage in water 


\section{S. M. Murray et al.}

snakes since similarities exist between the behavior of gamma rays and X-rays in DNA function.

Using Sample and Suter's model (1994) for estimating exposure of wildlife to toxicants, another aim was to produce a model for $\mathrm{Ni}$ and $\mathrm{U}$ exposure, and relate the estimated exposure values to biological effects. This model is used by both the USEPA and the USDOE in the risk assessment process, and is based on all exposure pathways. An exposure model for a semi-aquatic organism with an aquatic food base, such as $N$. fasciata (used in this study), has not been previously attempted. Although exposure from all pathways $\left(\mathrm{E}_{\text {total }}\right)$ is the sum of oral, dermal, and inhalation exposure, the estimates calculated here were only for oral exposure that included food and incidentally ingested soils. Several studies have indicated diet as the major exposure pathway for snakes (Fontenot et al. 2000; Hopkins et al. 2002). Inhalation and dermal exposure are considered minimal since the moisture level in this sytem is extremely high thus reducing air-borne particles and the aquatic nature of the snakes would preclude dermal exposure since most emmissions from the beta and gamma-emitting daughter products of $U$ as well as $U$ itself will not penetrate far enough into the water (contamination is within the stream sediments) to cause exposure. Specifically, Nerodia spend much of their time in trees to seek prey and then dive into the water to obtain the prey at which most of their time is spent in the upper portions of the water column. Further, diffusion of metals across the skin is negligible (as compared to susceptible taxa such as anurans).

The specific objectives of this study were to: determine the home range of $N$. fasciata to estimate $\mathrm{Ni}$ and $\mathrm{U}$ exposure; determine the $\mathrm{Ni}, \mathrm{U}$ and other associated metal concentrations in blood and tail snips of water snakes; compare the degree of DDSB found in the blood of water snakes collected from contaminated and reference sites; model the relationship between DDSB in water snakes with blood and tail snips metal concentrations. Using a field-based approach to examine ecological risk is unfortunately still relatively novel in the field of ecotoxicology, where the majority of studies are laboratory-based to avoid the burdens associated with natural variation. Although performing such studies in the field inherently adds more uncertainty and thus increases the need for sample sizes that can rarely be achieved (especially when focusing on a top predator), the ecological risk assessment field will not move forward until we examine the relationships between exposure estimates and endpoint effects in contaminated systems.

\section{MATERIALS AND METHODS}

\section{Study Site}

The Steed Pond-Tim's Branch depositional system (Figure 1) is located in the northwestern portion of the SRS, a $777 \mathrm{~km}^{2}$ USDOE facility in the upper coastal plain of South Carolina (Pickett 1990). This stream system was impacted during the 1950 s and the 1980s by discharges of depleted and natural $\mathrm{U}, \mathrm{Al}, \mathrm{Ni}, \mathrm{Cu}, \mathrm{Cr}, \mathrm{Zn}$, $\mathrm{Pb}$, and other metals associated with nuclear production (Punshon et al. 2003a). Steed's Pond was used as a settling basin for contaminated sediments as a result of fuel and target processing activities. It is estimated that $44,000 \mathrm{~kg}$ of depleted U was released into Steed's Pond (Pickett 1990; Punshon et al. 2003a,b). The breach of a 


\section{$\mathrm{Ni}$ and $\mathrm{U}$ in Water Snakes}

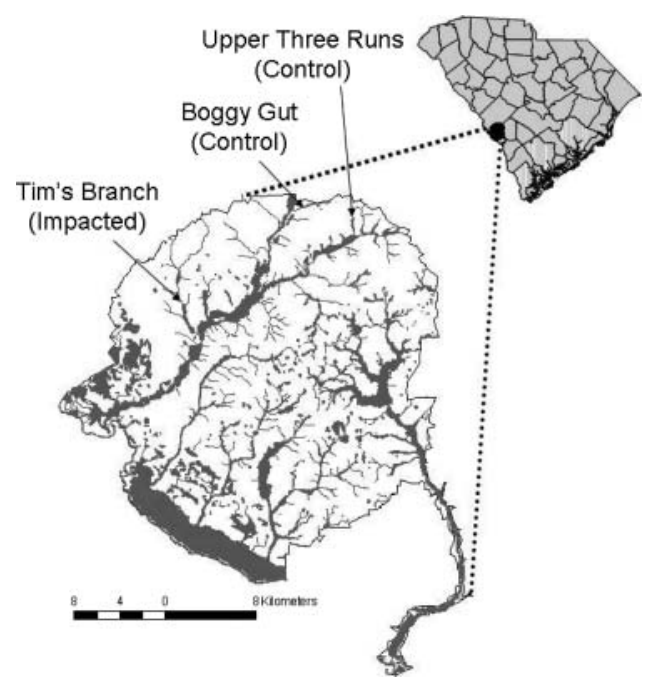

Figure 1. Map of the U.S. Department of Energy's Savannah River Site (SRS) located in west-central South Carolina, USA. Impacted and reference areas are shown in relationship to the wetlands and drainage system of the SRS (in gray).

wooden spillway in 1984, caused U and Ni contaminated sediment to flow into Tim's Branch. Downstream from Steeds Pond, along the Tim's Branch riparian area, is a beaver pond, hereafter referred to as Beaver Pond. The last wetland type along this watershed is a farm pond (Pond 25), which has also reverted to a stream after the failure of its dam from the influx of water from the Steed's Pond failure. Punshon et al. (2003a) indicated that U in Steed's Pond did not accumulate in high levels in the tissues of either cotton rats (Sigmodon hispidus) or marsh rice rats (Oryzomys palustris). However, $\mathrm{Ni}$ was shown to be bioavailable and accumulated in leaf tissues of black willow (Salix nigra) greater than published "background" concentrations. Similarly, Ni concentrations were elevated in liver and muscle tissues in both cotton rats and marsh rice rats from this site (Punshon et al. 2003b).

\section{Field Collection and Home Range}

Snakes (N. fasciata, N. taxispilota, and A. piscivorous) were collected during the months of April 2001 through July 2002 to account for seasonal differences in population abundance and heavy metal loads. Minnow traps were set at three locations within the impacted water shed (Steed's Pond, Beaver Pond, Pond 25) and at two reference areas (Boggy Gut and Upper Three Runs, Figure 1). The two reference sites are not a part of the Steed's Pond watershed. These sites have been commonly used as reference areas for SRS-based contaminant studies since there have been no reported disturbances to these sites from operations, and therefore are presumed to be representative of southeastern U.S. watersheds. To assess toxicant body burdens in prey, fishes and amphibians that are considered common prey items of $N$. fasciata (Gibbons and Dorcas 2004), were collected from the minnow traps set at each of the study sites for use in exposure estimation. Snakes captured in the field were brought 


\section{S. M. Murray et al.}

to the lab for no more than 2 days to obtain blood and muscle tissue samples and for morphometric measurements (snout-vent length, body weight, sex). A 8-10 mm of the tail tip (considered a muscle sample) was snipped as a representative for whole body tissue metal burden. At that time the tail blood was allowed to drip into two centrifuge tubes where 1-3 cc of blood was collected. Samples were immediately put on ice and transported to a $-80^{\circ} \mathrm{C}$ freezer to await analysis. These activities were conducted under the Rutgers University (97-017) and University of Georgia's (A960205) animal care and use protocols.

$N$. fasciata with a mass greater than $100 \mathrm{~g}$, caught during field collection (except for one-month prior to end of the activity season to allow for a tracking period) were fitted with a $5.0 \mathrm{~g}$ radio-transmitter manufactured by Holohil ${ }^{\circledR}$. Transmitters were implanted by subcutaneous placement following the use of Ketamine to anaesthetize the snake at rate of $0.77 \mathrm{ml} / \mathrm{kg}$ (Reinert and Cundall 1982). When the snakes were fully anaesthetized, an incision was made at a pre-sterilized site in the latter $1 / 3$ of the snout-vent length. The transmitter was inserted ventrally and placed so that the ribs "comfortably" surround it with the antenna threaded subcutaneously and anteriorly to allow for maximum reception. After transmitter insertion, the incision was closed using 4-0 gauge absorbable suture. Snakes were housed for one night with no water (to prevent drowning), in aquaria with dark shelter boxes and a heat strip. After the first night, water was placed back into the aquaria and the snakes monitored daily until normal activity appeared and no complications were observed. They were then released at the point of capture.

After release, each snake was located using radio-telemetry. Locations were determined by either triangulation or visual location. A global positioning system (GPS) was used to mark the animal's location or to mark radio-telemetry triangulation stations. Compass bearings were taken at a minimum of three stations and recorded onto a field map with a protractor. The bearings were then translated into ArcView@ and $\mathrm{x}$ - $\mathrm{y}$-coordinates were calculated to quantify home range. A minimum of 30 location points was determined to adequately minimize variance for the home range estimate (Worton 1987). A minimum period of $12 \mathrm{~h}$ was used between tracking sessions to prevent temporal autocorrelation between locations (Swihart and Slade 1985). Data points were collected at least once for each hour of the day as the maximal activity period (nocturnal v. diurnal) for $N$. fasciata is not known with certainty but also varies with season (Mills et al. 1995). Tracking was only performed weekly during the period of November through February (the typical hibernating period for snakes in the Southeast) once it was determined that individuals were indeed hibernating. Home range was quantified using CALHOME (Kie et al. 1996), utilizing the adaptive kernel method (Worton 1989).

\section{Exposure Estimates for Ingestion}

Oral exposure was estimated using the model described by Sample and Suter (1994) that utilizes the home range of an animal proportional to the size and utilization of the contaminated area expressed as body-weight normalized daily dose (mg/kg/day; Eq. (1)). Mean exposure estimates from food ingestion for the Tim's Branch watershed and the reference areas, Boggy Gut and Upper Three Runs, were determined using the data gathered from this study as well as previous 


\section{$\mathrm{Ni}$ and $\mathrm{U}$ in Water Snakes}

studies on and off the SRS. Specifically, fishes and amphibians that are considered common prey items of $N$. fasciata (as cited in Gibbons and Dorcas 2004) were collected from the minnow traps set at each of the study sites for use in exposure estimation. These species were: bluegill and dollar sunfish (Lepomis marginatus), golden shiners (Notemigonus crysoleucas), red-fin pickerel (Esox americanus), pirate perch (Aphredoderus sayanus), green frog (Rana clamitans), and the southern toad (Bufo terrestris). Exposure was estimated using the concentration of $\mathrm{Ni}$ and $\mathrm{U}$ in each food type (amphibians, fishes), ingestion rate (0.26 g/g-day; Brown 1958; USEPA 1992), body weight (mass), waste site area (ha; from GIS-based contaminant distribution data layers), and home range size (ha) of endpoint species ( N. fasciata) as determined from the home range portion of the study. The water in the Tim's Branch system was not contaminated (unpublished data) and soil ingestion rates for piscivores (and those animals that consume amphibians) are considered negligible (Sample and Suter 1994). Therefore exposure was estimated as:

$$
E_{j}=\left(\frac{A}{H R}\left[\sum_{i=1}^{m}\left(\frac{F I R_{i} * C_{i j}}{B W}\right)\right]\right)
$$

where: $E_{j}=$ total exposure to contaminant $(j)(\mathrm{mg} / \mathrm{kg} / \mathrm{d}), m=$ total number of ingested media (e.g., food, water, or soil), FIR $_{\mathrm{i}}=$ food ingestion rate $(i)(\mathrm{kg} / \mathrm{d}$ or liter/d); see Eq. (2), $C_{i j}=$ concentration contaminant $(j)$ in medium $(i)$ ( $\mathrm{mg} / \mathrm{kg}$ or $\mathrm{mg} / \mathrm{l}), B W=$ body weight of endpoint species $(\mathrm{kg}), A=$ area (ha) of the waste site, $H R=$ home range size $($ ha $)$ of endpoint species.

Food ingestion rates $\left(F I R_{d r y}\right)$ were calculated based on models of the northern water snake ( $N$. sipedon) presented in the Wildlife Exposures Factors Handbook (USEPA 1993), which were calculated using data from Brown (1958). Differences in ingestion rates between the two species, previously classified taxonomically as the same species, are likely to be insignificant. This ingestion rate was converted to fresh weight to reflect what the animal is ingesting in the field by considering the water content of the food, by using the following formula:

$$
\mathrm{FIR}_{\mathrm{fresh}}=\sum_{i=1}^{f}\left(P_{i} \times \frac{F I R_{d r y}}{1-W C_{i}}\right)
$$

where: $\mathrm{FIR}_{\text {fresh }}=$ total food ingestion rate $\left(\mathrm{kg}\right.$ food $\mathrm{d}_{\text {fresh weight }} /$ individual $/$ day $), P_{i}=$ proportion of the $i$ th food type in the diet, $W C_{i}=$ proportional water content (by weight) of the $i$ th food type (as determined from drying the potential food items prior to metal analysis).

Four diet composition scenarios were used to estimate exposure based on Brown (1958): (1) 100\% amphibians/0\% fish; (2) $79 \%$ amphibians $/ 21 \%$ fish; (3) $21 \%$ amphibians $/ 79 \%$ fish; (4) $0 \%$ amphibian/100\% fish. Amphibian species were pooled for analyses because preliminary Analysis of Variance (ANOVA) results showed no differences in toxicant load between the two species. Loads differed significantly between fish species, however, and subsequently were not combined. Since fish dietary preference for $N$. fasciata has not been recorded, each of the four fish species assumed equal contribution to exposure at $25 \%$.

Calculated home range for N. fasciata (HR) was overlayed on top of waste site boundaries within a GIS (ArcView (C)) and it was determined that the area of the 


\section{S. M. Murray et al.}

home range was smaller than the contaminated area (A). Therefore, the waste site area-to-home range ratio equaled one (1) and dropped from the model. Exposure for $N$. fasciata was divided into two age classes: juvenile and adult based on the minimum snout-vent length observed at sexual maturity $(52 \mathrm{~cm}$ for males and $58 \mathrm{~cm}$ for females; Tinkle 1959). However, preliminary ANOVA models indicated that no differences existed based on sex; therefore, exposures were only calculated separately by age group.

\section{Metal Analyses}

After collection, blood and muscle tissue samples were freeze-dried and digested with $5 \mathrm{ml} 5 \mathrm{M} \mathrm{HNO}_{3}$ (trace metal grade) in pure Teflon(tm) PFA vessels using microwave digestion apparatus (MDS-2000, CEM Corporation, Matthews, NC). A $\mathrm{HNO}_{3}$ blank and a U.S. National Institute of Standards and Technology (NIST) standard reference material (TORT) were included with each carousel after which samples were analyzed using inductively coupled plasma-mass spectrometry (ICPMS). Ni concentrations in prey items were determined in the same way as the blood and tail snips. Animals were freeze-dried, digested using the whole body to reflect what the snake ingests, and analyzed using ICP-MS. Digested tissue samples followed a modified methodology outlined in USEPA method 3052 and quality control procedures based on USEPA method 6020.

\section{DNA Double-Strand Breakage}

Blood samples for DNA double-strand breakage (DDSB) were taken from fieldcaptured snakes (N. fasciata, N. taxispilota, A. piscivorous). After snipping, the tail blood was allowed to drip into two centrifuge tubes. Tubes contained a mixture of heparin and high salt SDE buffer to prevent clotting and stabilize the mixture to keep cell disruption to as low a level as possible. Samples were immediately put on ice and thereafter into a freezer at $-20^{\circ} \mathrm{C}$ until lab analyses were performed.

DNA samples were prepared for agarose-based Pulsed Field Gel Electrophoresis (PFGE). Blood samples were first embedded in agarose plugs and then incubated with proteinase $\mathrm{K}$ for a minimum of $12 \mathrm{~h}$. After this treatment, the samples were run on a BIORAD CHEF-DR ${ }^{\circledR}$ III (Clamped Homogeneous Electrical Field) PFGE unit. Methods for the running gel were as follows: $16-\mathrm{h}$ run, 4.5 volts $/ \mathrm{cm}, 120^{\circ}$ angle of current, and a ramp of 40-120 s between "switching" angles. Each gel contains 45 lanes consisting of ten samples replicated once and three size markers and a blank lane between all sample lanes. A second gel containing the same samples but in a random order was run for a second replication between gels. The size markers are Hi-Lo (50 base pairs to 10 kilobase pairs), 10-200 (0.1 kilobases to 194 kilobases), and yeast chromosomes (Saccharomyces cerevisiae; 225 kilobases to 2,200 kilobases). After the gel was run, it was allowed to soak in SyberGold ${ }^{\circledR}$ stain solution on a shaker table for $1 \mathrm{~h}$ for later UV visualization. The gel was then photographed under UV light, and the images were quantified as presence or absence of double-strand breakage. Longer, unbroken pieces of DNA (approx. 3M bases and larger) are expected to remain in the well. Each sample was replicated four times (twice within gels and twice between gels) to quantify and remove handling artifacts. Presence of breakage was determined using all replicates of an individual. 


\section{$\mathrm{Ni}$ and $\mathrm{U}$ in Water Snakes}

\section{Statistical Analyses}

A one-way ANOVA (with Bonferroni corrections), revealed no statistical differences between toxicant concentrations in blood or muscle tissues within the contaminated site types and reference site types; therefore, the two reference sites, Boggy Gut and Upper Three Runs, were combined in addition to the three contaminated sites, Tim's Branch, Beaver Pond, and Steed's Pond (PROC GLM, SAS@) Institute 2003). Individual one-way ANOVA's of blood and muscle for both species of water snake and A. piscivorous, were used to examine differences in toxicant body burdens for each species between sampling locations (PROC GLM; SAS@ Institute 2003). Stem-and-leaf and normality plots suggested log-transformation prior to analysis (PROC UNIVARIATE; SAS@ Institute 2003). After transformation, all variables were normally distributed. Statistical significance was tested at the $\alpha=0.05$ level.

The relationship between DDSB versus toxicant concentration in blood and muscle was established based on assigning each individual a score of either broken or unbroken by assessing all the replicates for each individual. A log-likelihood ratio test $(G)$ was used to determine the extent of damage between the reference site and Tim's Branch for all snakes (including A. piscivorous) and for $N$. fasciata alone, based on the expected number of strand breaks from the reference site (Zar 1999). For DDSB, no statistical difference existed within the contaminated site types or reference sites types at the $\alpha=0.05$ level, therefore, the two reference sites, Boggy Gut and Upper Three Runs, were combined, as well as the three contaminated sites; Tim's Branch, Beaver Pond, and Steed's Pond.

A logistic regression model was used to determine how the metal body burdens were related to the probability of breakage (PROC LOGISTIC, SAS@ Institute 2003). We used an information-theoretic model fitting procedure (Burnham and Anderson 2002) to fit the most parsimonious model. Specifically, the corrected Akaike Information Criterion (AICc) was utilized as the information-theoretic statistic for the procedure (Akaike 1974). All variables in all models were tested for collinearity utilizing a principal components analysis of matrix structure. Metals were eliminated individually one by one from the model based on their correlation to the dependent variable (the independent variable with the lowest correlation was removed first) as long as the AICc continued to decrease. A final logistic regression model was determined when the AICc stabilized or increased. Individual logistic regressions were run for the log-transformed values of the eight metals $(\mathrm{Al}, \mathrm{Ni}, \mathrm{Cr}, \mathrm{Cu}, \mathrm{Se}, \mathrm{Mn}$, $\mathrm{U}$, and $\mathrm{Hg}$ ). We chose these particular metals because of their prevalence in the soil and plant tissues of the Tim's Branch watershed (Table 1), and to further examine trophic differences in concentrations (Punshon et al. 2003a,b).

A correlation analysis was used to determine the association of metals between the blood and muscle samples (PROC CORR, SAS@ Institute 2003). This was done to estimate the relative independence of metal concentrations between the tissue types.

\section{RESULTS}

\section{Home Range}

Twelve $N$. fasciata were tracked from the three experimental sites (Steed's Pond, Beaver Pond, and Pond 25; Figure 1). The mean home range area for the 12 snakes 


\section{S. M. Murray et al.}

Table 1. Comparison of $\mathrm{U}$ and Ni concentrations in reference areas and Steed's Pond media (located on the Department of Energy's Savannah River Site (South Carolina, USA)) as reported from a simultaneous study (Punshon et al 2003b).

\begin{tabular}{lcc}
\hline Compartment & $\begin{array}{c}\text { Mean U concentration } \\
(\mathrm{mg} / \mathrm{kg})(\mathrm{SE})\end{array}$ & $\begin{array}{c}\text { Mean Ni concentration } \\
(\mathrm{mg} / \mathrm{kg})(\mathrm{SE})\end{array}$ \\
\hline Soils $($ reference) $(\mathrm{n}=3)$ & $8.15(0.850)$ & $26.2(1.20)$ \\
Steed Pond Soil $(\mathrm{n}=3)$ & $1675.5(382.1)$ & $876.5(197.7)$ \\
Salix nigra (reference) $(\mathrm{n}=5)$ & $<\mathrm{BDL}$ & $4.7(5.8)$ \\
Salix nigra $($ leaf tissue $)(\mathrm{n}=5)$ & $0.03(0.002)$ & $75.5(3.6)$ \\
\hline
\end{tabular}

$<$ BDL: Below detection limits.

was 1.77 ha $(\mathrm{SE}=0.24)$. Individual home ranges overlapped in almost all cases between and among the sexes, except at Pond 25. During the tracking period, June 2001 to August 2002, the southeastern U.S. experienced the tail end of a 5-year drought. Regardless of wetland hydrology, it was found that each snake remained within the geographical boundaries of each wetland. No differences in home range as a function of gender were found, and there was no linear association between home range and snout-vent length or body weight for this species $(p>.05$ for all tests).

\section{Metal Concentrations}

$\mathrm{U}$ and Ni concentrations in water snake prey items from Tim's Branch used for exposure estimates were elevated compared to the control areas (Tables 2-3). Both blood and muscle metal concentrations tended to be higher in the contaminated areas versus the control areas (Table 4). Blood Ni levels were significantly greater in snakes from Tim's Branch than the reference area $(p<.0001)$ for $N$. fasciata. No other metal in N. fasciata blood was significantly different between Tim's Branch and the reference area.

In the muscle tissue, $\mathrm{U}$ was the only metal found to be significantly greater in the Tim's Branch $N$. fasciata compared to the reference area $(p<.0001)$. U was also found to be significantly greater $(p=.0002)$ in muscle tissues of $A$. piscivorous from the Tim's Branch area. There was no difference between metal loads in N. taxispilota blood or muscle tissue. No relationship existed between body burden and sex, mass, or snout-vent length.

$\mathrm{Cu}$ exhibited a strong negative correlation while Se exhibited a strong positive correlation between blood and muscle when all snakes were pooled and when $N$. fasciata was evaluated alone (Table $5 ; p$ 's $<.05$ ). U had a weak positive correlation with muscle and blood with the relationship similar whether all species were pooled or if $N$. fasciata was evaluated alone. All other metals exhibited no correlation between muscle and blood.

\section{fasciata Exposure Estimates}

U exposure from the Tim's Branch watershed is 2-3 orders of magnitude greater than that which is predicted for the reference site (Table 3). For Ni, the exposure 
Table 2. Mean metal concentrations (fresh weight $\mathrm{mg} / \mathrm{kg}$ (standard error)) of potential Nerodia fasciata food items ( $\mathrm{n}=$ \# of samples) collected from contaminated areas on the Tim's Branch watershed and a reference area located on the Department of Energy's Savannah River Site (South Carolina, USA). (a.) U concentrations in prey items. (b.) $\mathrm{Ni}$ concentrations in prey items.

(a)

\begin{tabular}{lll} 
Food item & \multicolumn{1}{c}{ U contaminated } & \multicolumn{1}{c}{ U reference } \\
\hline Amphibians & $0.485(0.101) ; \mathrm{n}=36$ & $0.004(0.002) ; \mathrm{n}=14$ \\
Minnows & $0.399(.067) ; \mathrm{n}=25$ & $0.005(0.001) ; \mathrm{n}=14$ \\
Perch & $0.213(.023) ; \mathrm{n}=41$ & $0.004(0.001) ; \mathrm{n}=15$ \\
Pike & $0.100(0.020) ; \mathrm{n}=24$ & $0.001(0.0001) ; \mathrm{n}=29$ \\
Sunfishes & $0.203(0.020) ; \mathrm{n}=42$ & $0.009(.002) ; \mathrm{n}=2$ \\
\hline \multicolumn{1}{c}{$(\mathrm{b})$} & Ni contaminated & \\
Food item & $0.501(0.096) ; \mathrm{n}=36$ & Ni reference \\
\hline Amphibians & $0.476(.065) ; \mathrm{n}=25$ & $0.455(0.137) ; \mathrm{n}=14$ \\
Minnows & $0.764(.077) ; \mathrm{n}=41$ & $0.134(0.052) ; \mathrm{n}=14$ \\
Perch & $0.619(0.191) ; \mathrm{n}=24$ & $0.489(.098) ; \mathrm{n}=15$ \\
Pike & $0.319(0.062) ; \mathrm{n}=42$ & $0.248(0.074) ; \mathrm{n}=29$ \\
Sunfishes & & $0.197(0.115) ; \mathrm{n}=2$ \\
\hline
\end{tabular}

from Tim's Branch is nearly double that of the reference site. The majority of U exposure from Tim's Branch is attributed to ingestion of amphibians. Also, as a function of the exposure equation, exposure decreased from juvenile to adult due to body mass for both metals.

\section{DNA Double-Strand Breakage}

The log-likelihood ratio test indicated significantly greater breakage in all species, as well as $N$. fasciata alone, from the Tim's Branch area compared to individuals from the reference area (Figure $2, \mathrm{G}=18.27, p<.0001$ ). In both instances, breakage from Tim's Branch was approximately three times more likely. Slope estimates for the metals that were included in the logistic regression model relating them to the probability of strand breakage for all species and $N$. fasciata-blood and muscle tissues are shown in Table 6. No meaningful model could be fitted for blood pooled for all species. The strongest model, yielding a max-rescaled $r$-square value of 0.53 , was for $N$. fasciata-blood indicating that $\mathrm{Cr}, \mathrm{Hg}, \mathrm{Ni}$, and $\mathrm{Se}$ positively related to strand-breakage, while $\mathrm{Al}, \mathrm{Cu}$, and $\mathrm{U}$ were negatively related.

\section{DISCUSSION}

Bioaccumulation of toxicants in snakes has been demonstrated in several studies (Burger and Gibbons 1998; Hopkins 2000; Hopkins et al. 1999; Ohlendorf et al. 1988). Specifically, Hopkins (2000) has shown blood sampling and tail clips in $N$. fasciata as a possible means to demonstrate heavy metal burden within the organism 


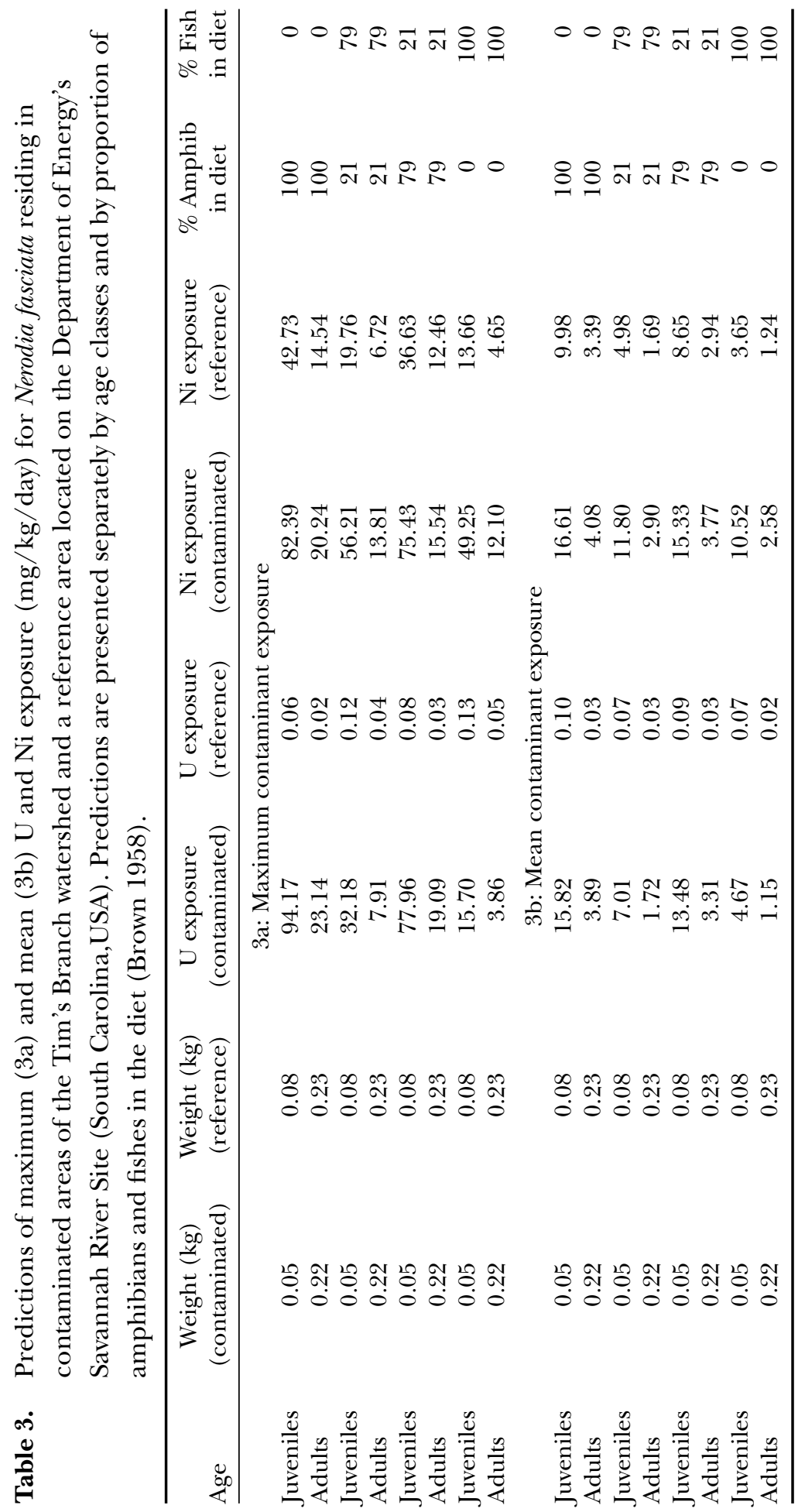




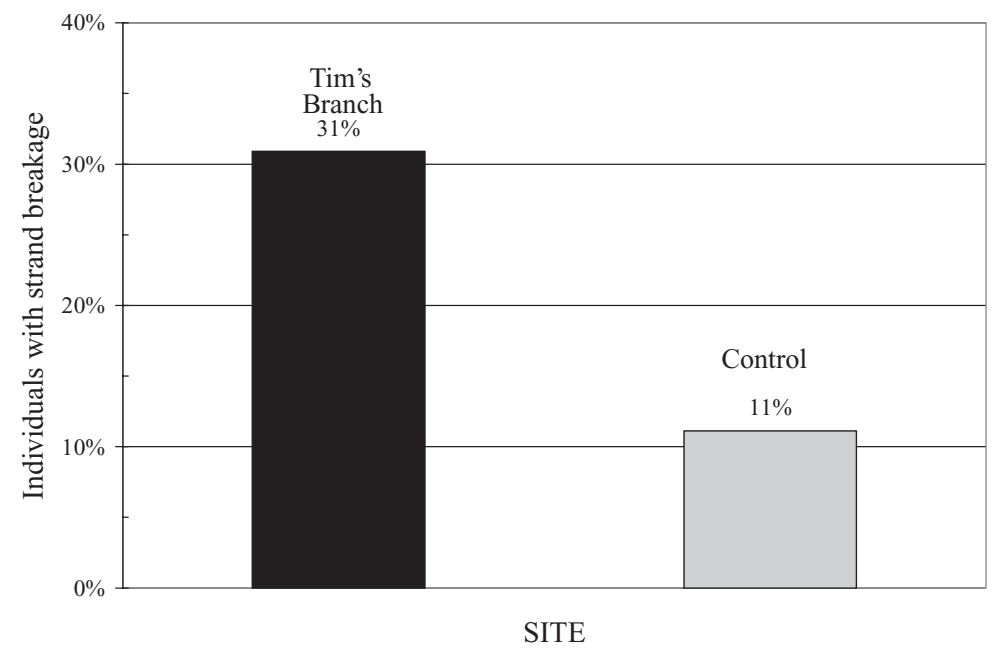

Figure 2. DNA double strand breakage (DDSB) expressed for all species of water snakes (Nerodia fasciata, N. taxispilota, and Akistrodon piscivorou; $\mathrm{G}=18.27$, $d f=1, p<.0001)$. The black bar represents percentage of DDSB in blood of snakes from Tim's Branch $(n=55)$ and the gray bar represents percent breakage from the control sites $(n=20)$.

and reported tail snips and blood samples as good predictors of arsenic exposure. However, in this study, data did not indicate a correlation between the tissue types (blood and tail) for the particular metals analyzed, and blood concentrations did not reflect whole body exposure (Tables 3-5). These contrasting results are likely due to sample size differences, magnitude of contamination, and chemical behavior of the different metals. Specifically, since so many toxicants are present in the contaminated watershed, the permutations of their chemical interactions in the environment are extremely complex to model. The logistic regression showed a relationship between DDSB and metals (Table 6). However, these models only explain a portion of the variation due to environmental stochasticity. Bioavailability of metals may increase or decrease with the presence or absence of other specific metals depending on the mixture and other abiotic factors surrounding the matrix (Pyle et al. 2002; Stewart 1999). Our study showed a repeated association between Se and U, which prompts further investigation. The influence of Se on metal bioavailability is not surprising as the protective effects of $\mathrm{Se}$ on $\mathrm{Hg}$ uptake have been documented by several reports (see Burger et al. 2001). In this study, Se had an opposite directionality to $\mathrm{U}$ in each of the four logistic regression models (Table 6).

\section{U and Ni Exposure}

Previous studies in the Tim's Branch watershed have shown that levels of both metals residing in the soil, and plant tissues, are heterogeneously distributed (Punshon et al. 2003a,b). The home ranges of $N$. fasciata showed that this animal resided exclusively within the contaminated area during the entire study period. Exposure within the contaminated area of Tim's Branch was greater than the reference area, 


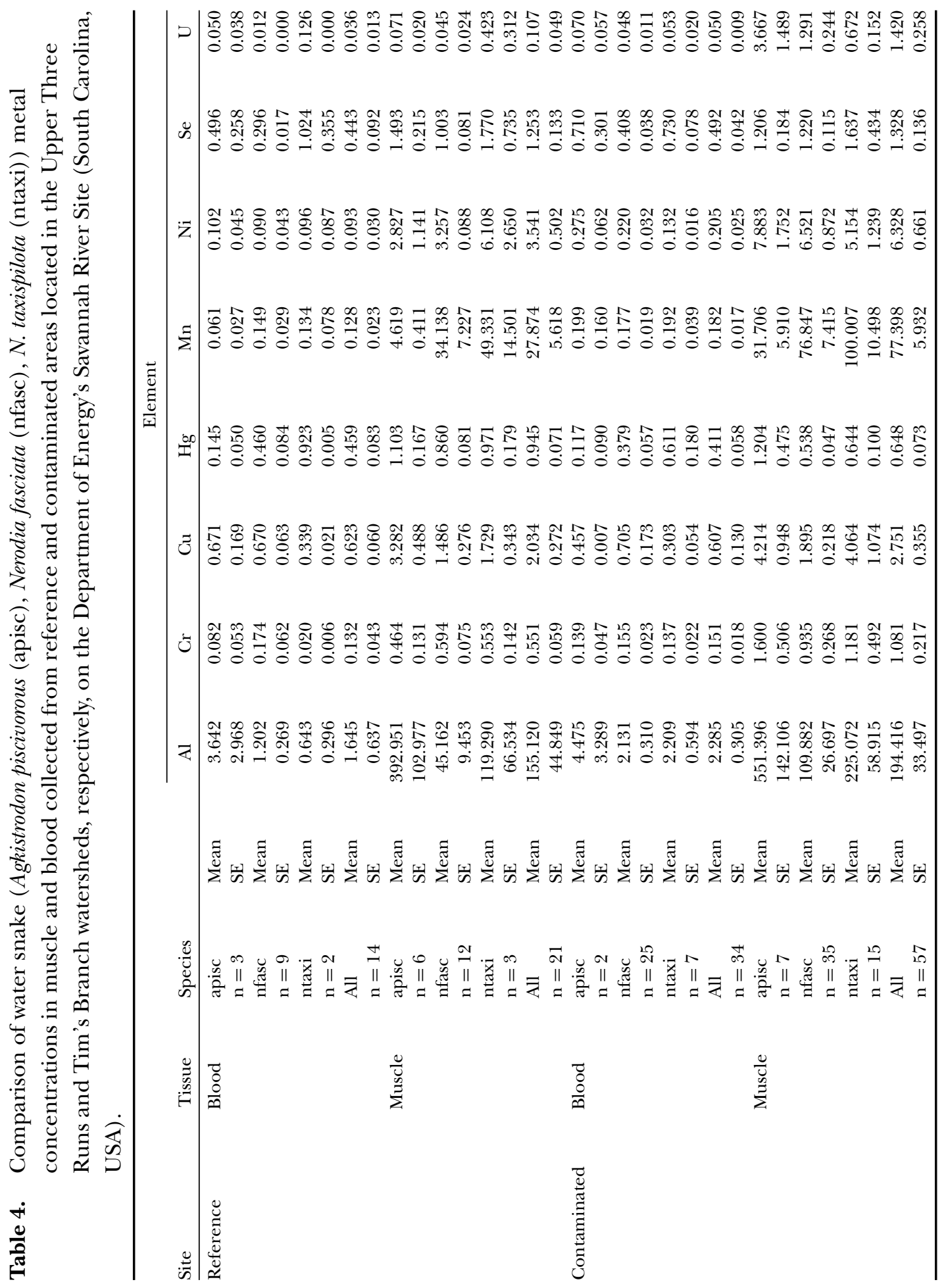


Table 5. Pearson correlation coefficients for blood and muscle tissues in pooled individuals of all snake species $(\mathrm{n}=57)$ as well as only Nerodia fasciata $(\mathrm{n}=38)$ individuals from the Department Energy's Savannah River Site located in South Carolina, USA.

\begin{tabular}{lrrrrr}
\hline & \multicolumn{2}{c}{ All species } & \multicolumn{2}{c}{ Nerodia fasciata } \\
\cline { 2 - 3 } Metal & $r$-value & $p$-value & & $r$-value & $p$-value \\
\hline $\mathrm{Al}$ & -0.0110 & 0.9407 & & -0.2489 & 0.1557 \\
$\mathrm{Ni}$ & -0.0002 & 0.9988 & & -0.0631 & 0.7229 \\
$\mathrm{Cr}$ & 0.0457 & 0.7576 & & -0.1487 & 0.4012 \\
$\mathrm{Cu}$ & -0.5903 & $<0.0001$ & & -0.6160 & 0.0001 \\
$\mathrm{Se}$ & 0.5288 & 0.0001 & 0.4187 & 0.0137 \\
$\mathrm{Mn}$ & 0.0433 & 0.7702 & & -0.1777 & 0.3148 \\
$\mathrm{U}$ & 0.2552 & 0.0800 & 0.3025 & 0.0821 \\
$\mathrm{Hg}$ & 0.1007 & 0.4960 & 0.1950 & 0.2691 \\
\hline
\end{tabular}

especially for $\mathrm{U}$, which was 2-3 orders of magnitude greater than the reference area. Interestingly, the majority of U exposure from Tim's Branch was due to the predicted consumption of amphibians. Amphibians collected from Tim's Branch had higher $U$ burdens than fish collected from the same site (Table 2). Notably, the relationship between exposure and uptake was demonstrated with $N$. taxispilota residing in contaminated areas that had markedly lower concentrations of $\mathrm{Ni}$ and $\mathrm{U}$ in blood or tissue samples compared to other snake species. Although N. taxispilota were excluded from the exposure analysis due to sample size limitations, their diet, which consists almost exclusively of fishes (Mills et al. 1995), bolsters the inference that fish may not be the vector for U or Ni exposure in Tim's Branch. This parallels exposure assessments conducted for wild hogs (Sus scrofa) for Tim's branch showing that both $\mathrm{Ni}$ and $\mathrm{U}$ exposure was related to diet (Gaines et al. 2005).

The Agency for Toxic Substances and Disease Registry (ATSDR) has derived a minimal risk level (MRL) for soluble compounds of $U$ of $0.002 \mathrm{mg} / \mathrm{kg} /$ day based on the lowest observed adverse effect level (LOAEL) of $0.05 \mathrm{mg} / \mathrm{kg} /$ day for renal effects in rabbits (ATSDR 1999; Gilman et al. 1998). Mean U exposure from reference areas ranged from $0.02-0.1 \mathrm{mg} / \mathrm{kg}$ /day level (Table 2), exceeding the MRL. However, it is difficult to extrapolate what the MRL should be for reptiles since their physiologies differ from mammals. Since exposure estimates for both juvenile and adults from the impacted Tim's Branch study were up to three orders of magnitude greater than the reference area the potential for risk of an adverse effect for this population from oral exposure may be very real.

The mammalian oral reference dose (RfD) for $\mathrm{Ni}$ is $0.02 \mathrm{mg} / \mathrm{kg} /$ day (Ambrose and Paillet 1980; IRIS 1996). Exposure estimates to Ni for the control snakes exceeded the mammalian RfD by several orders of magnitude and snakes from the impacted areas had exposure estimates roughly double over the control snakes. Most likely due to depuration, concentrations of $\mathrm{Ni}$ in muscle tissue for this species did not significantly exceed those from the reference area, although the Ni concentration in the blood of $N$. fasciata was significantly greater from Tim's Branch than the reference area. 


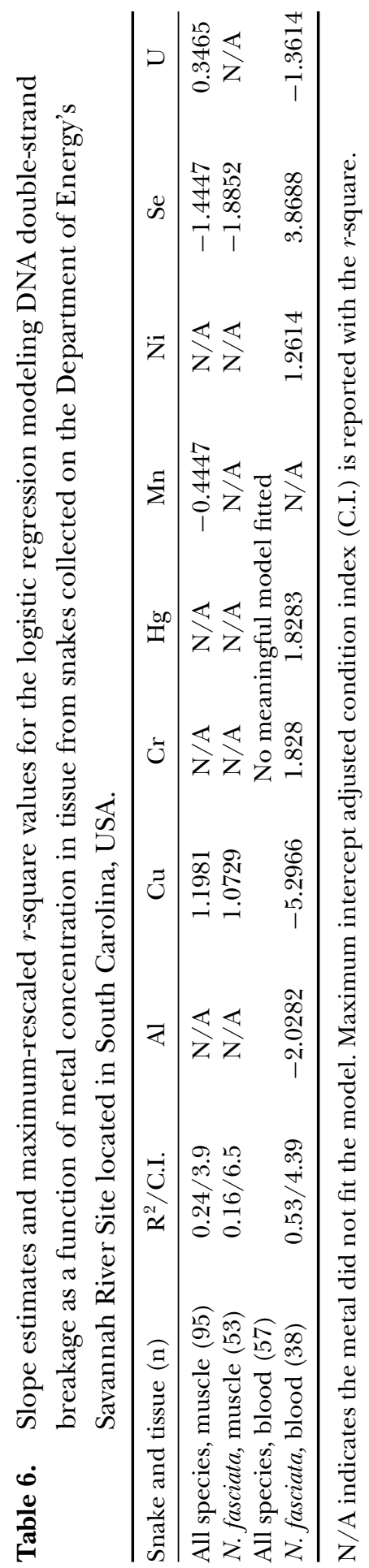




\section{$\mathrm{Ni}$ and $\mathrm{U}$ in Water Snakes}

\section{DNA Double-Strand Breakage (DDSB)}

Our findings showed that the snakes from the impacted site had higher DDSB compared to snakes from control locations, indicating that DDSB has the potential to be used as an endpoint to identify ecological risk. Hartwig (1995) suggested that the mechanism for metal-induced breakage is the inhibition of repair processes while Sugg et al. (1995) showed that adducted nucleotides produced by radiation may prevent the repair of naturally occurring strand breaks due to interference. This latter process occurs in addition to direct breakage from ionizing radiation or from induction of free radicals (Sugg et al. 1995). Heavy metals may also cause direct breakage through the induction of oxygen radicals (Hoffman and Heinz 1998; Snow 1991; Tsuzuki et al. 1994). The presence of $U$ in muscle tissue and the correlation to the observed DDSB (Table 6) allows speculation that gamma-emitting daughter products of U in Tim's Branch might have had some effect on the integrity of the DNA of these organisms. Since $U$ is a metal, an alpha emitting radionuclide with strong beta and gamma daughter products, the totality of its effect is combination of all of these components.

It was hypothesized that compounds of $\mathrm{Ni}$, which have been known to cause strand breakage, were possibly acting as agents to increase the background level of DNA strand breaks in water snakes. The logistic regression for the strongest model using $N$. fasciata blood showed this positive relationship of $\mathrm{Ni}$ as well as $\mathrm{Cr}, \mathrm{Hg}$, and Se with DDSB (Table 6). This finding is consistent with previous studies that have shown that the induction of DNA breaks by both Se and $\mathrm{Hg}$, which is mediated by the formation of active oxygen species (Hoffman and Heinz 1998, Tsuzuki et al. 1994). Hopkins et al. (2002) found that Se accumulation in N. fasciata fed food from a contaminated ecosystem on the SRS exceeded toxic thresholds. However, other studies have demonstrated a protective effect of Se on $\mathrm{Hg}$ exposure at the intracellular level (Lourdes 1991). Moreover, Cr is well known to inhibit DNA repair and can form intermolecular DNA cross-links (Snow 1991; Tsuzuki et al. 1994).

Interestingly, $\mathrm{U}, \mathrm{Al}$, and $\mathrm{Cu}$ in the blood exhibited a negative relationship with DDSB (Table 6). This may be due to the residence time of the metals in the respective tissues, with blood in general having faster metal depuration rates than muscle in reptiles (Sparling et al. 2000). Therefore, metals that tend to directly cause DDSB (rather than inhibit repair) might not be present in the blood long enough to cause DDSB. Conversely, if the toxicant inhibits repair, residence time is not as an important factor since this is a more continuous process. This can best be seen in the fitted model using muscle tissue for the three snake species combined that showed an inverse relationship with Se and Mn, no relationship between DDSB and $\mathrm{Ni}$, but a direct relationship with $\mathrm{U}$ and $\mathrm{Cu}$ (Table 6). Cu has also shown a direct relationship to DDSB (Lloyd and Phillips 1999), and U can break DNA due to its alpha emissions.

A suite of contaminants were deposited in the Tim's Branch system over the last 50 years and how they behave as a mixture warrants further consideration. The logistic regression analysis (Table 6) demonstrated the relative association of these contaminants acting as a mixture. The biogeochemistry of these metals may change and not behave in the field as independent agents. The mixtures may be additive, compensatory, minimizing, or all three, thereby complicating predicted transfer 


\section{S. M. Murray et al.}

pathways of the metals in the environment. More research to demonstrate relationships between genetic damage and combined contaminant exposure, uptake, and physiological response, is needed.

\section{ACKNOWLEDGMENTS}

This project was funded through the Financial Assistance Award DE-FC0996SR18546 from the U.S. Department of Energy to the University of Georgia Research Foundation. This research was also funded by the Consortium for Risk Evaluation with Stakeholder Participation (CRESP) through the U.S. Department of Energy (AI\#DE-FC01-95EW55084 and DE-FG26-00NT-40938) and NIEHS (ESO 5022). We thank Cub Stephens for overseeing and conducting extensive field work. S. J. Mullin and the Eastern Illinois University Herpetology Laboratory edited an earlier manuscript version, thus providing additional insights that improved this article. This article also benefited from the comments of four anonymous reviewers.

\section{REFERENCES}

Akaike H. 1974. A new look at the statistical model identification. IEEE Transaction on Automatic Control AC-19:716-23

Ambrose D and Paillet S. 1980. Induction of trifluorothymidine resistant mutants by metal ions in L5178YTK +/- cells. Mutat Res 78:279-88

ATSDR (Agency for Toxic Substances and Disease Registry). 1999. Toxicological Profile for Uranium. US Department of Health and Human Services, Public Health Service. Atlanta, GA, USA

Brown EE. 1958. Feeding habits of the Northern Water Snake, Natrix sipedon sipedon Linnaeus. Zoologica 43(Part 2):55-71

Burger J and Gibbons WJ. 1998. Trace elements in egg contents and egg shells of slider turtles (Trachemys scripta) from the Savannah River Site. Arch Environ Contam Toxicol 34:382-6

Burger J, Gaines KF, Boring CS, et al. 2001. Mercury and selenium in fish from the Savannah River: Species, trophic level, and locational differences. Environ Res 87:108-18

Burnham KP and Anderson DR. 2002. Model Selection and Multimodel Inference: A Practical Information-Theoretic Approach. Springer-Verlag, New York, NY, USA

Campbell KR and Campbell TS. 2001. The accumulation and effects of environmental contaminants on snakes: A review. Environ Monit Assess 70:253-301

Christie NT. 1989. The synergistic interaction of nickel (II) with DNA damaging agents. Toxic Environ Chem 22:51-59

Fontenot LW, Noblet GP, Akins JM, et al. 2000. Bioaccumulation of polychlorinated biphenyls in ranid frogs and northern water snakes from a hazardous waste site and a contaminated watershed. Chemosphere 40:803-9

Gaines KF, Porter DE, Punshon T, et al. 2005. A spatially explicit model of the wild hog for ecological risk assessment activities at the Department of Energy's Savannah River Site. Hum Ecol Risk Assess 11:567-589

Gibbons WJ and Dorcas ME. 2004. North American Watersnakes: A Natural History. University of Oklahoma Press, Norman, OK, USA

Gilman AP, Villenuve DC, Secours VE, et al. 1998. Uranyl nitrate: 91-day toxicity studies in the New Zealand white rabbit. Toxicol Sci 41:129-37

Hartwig A. 1995. Current aspects in metal genotoxicity. BioMetals 8:3-11 


\section{Ni and $\mathrm{U}$ in Water Snakes}

Hoffman DJ and Heinz GH. 1998. Effects of mercury and selenium on glutathione metabolism and oxidative stress in mallard ducks. Environ Toxicol Chem 17:161-6

Hopkins WA. 2000. Reptile toxicology: challenges and opportunities on the last frontier in vertebrate ecotoxicology. Environ Toxicol Chem 19:2391-3

Hopkins WA, Rowe CL, and Congdon JD. 1999. Elevated trace element concentrations and standard metabolic rate in banded water snakes (Nerodia fasciata) exposed to coal combustion wastes. Environ Toxicol Chem 18:1258-63

Hopkins WA, Roe JH, Snodgrass JW, et al. 2001. Nondestructive indices of trace element exposure in squamate reptiles. Environ Pollut 115:1-7

Hopkins WA, Roe JH, Snodgrass JW, et al. 2002. Trace element accumulation and effects of chronic dietary exposure on banded water snakes (Nerodia fasciata). Environ Toxicol Chem 21:906-13

IRIS (Integrated Risk Information System). 1996. Nickel, soluble salts. Available at http: //www.epa.gov/iris/subst/0271.htm

Kie JG, Baldwin JA, and Evans CJ. 1996. CALHOME: A program for estimating animal home ranges. Wildl Soc Bull 24:342-4

Lamb T, Bickham JW, Gibbons WJ, et al. 1991. Genetic damage in a population of slider turtles (Trachemys scripta) inhabiting a radioactive reservoir. Arch Environ Contam Toxicol 20:138-42

Lloyd DR and Phillips DH. 1999. Oxidative DNA damage mediated by copper(II), iron(II) and nickel(II) Fenton reactions: Evidence for site-specific mechanisms in the formation of double-strand breaks, 8-hydroxydeoxyguanosine and putative intrastrand cross-links. Mut Res/Fund Mol Mech Mut 424:23-36

Lourdes MA, Culvin-Aralar A, and Furness RW. 1991. Mercury and selenium interaction: A review. Ecotoxicol Environ Safety 21:348-64

Mills MS, Hudson CJ, and Berna HJ. 1995. Spatial ecology and movements of the brown water snake (Nerodia taxispilota). Herpetelogica 51:412-23

Ohlendorf HM, Hothem RL, and Aldrich TW. 1988. Bioaccumulation of selenium by snakes and frogs in the San Joaquin Valley, California. Copeia 1988:704-10

Pickett JB. 1990. Heavy Metal Contamination in Tim's Branch Sediments. OPS-RMT-900200. Westinghouse Savannah River Company, Aiken, SC, USA

Punshon T, Gaines KF, Bertsch PM, et al. 2003a. Bioavailability of uranium and nickel to vegetation in a contaminated riparian ecosystem. Environ Toxicol Chem 22:1146-54

Punshon T, Gaines KF, and Jenkins RA, Jr. 2003b. Bioavailability and trophic transfer of sediment-bound $\mathrm{Ni}$ and $\mathrm{U}$ in a southeastern wetland system. Arch Environ Contam Toxicol 44:30-5

Pyle G, Swanson S, and Lehmkuhl D. 2002. Toxicity of uranium mine receiving waters to early life stage fathead minnows (Pimephales promelas) in the laboratory. Environ Pollut 116:243-55

Reinert HK and Cundall D. 1982. An improved method for radio-tracking snakes. Copeia 1982:702-5

Sample BE and Suter GW II. 1994. Estimating Exposure of Terrestrial Wildlife to Contaminants. ES/ER/TM-125. Environmental Science Division, Oak Ridge National Laboratory, Oak Ridge, TN, USA

Shugart LR and Gustin MK. 1989. Susceptibility of DNA in aquatic organisms to strand breakage: Effect of X-ray and Gamma radiation. Mar Environ Res 28:339-43

Snow ET. 1991. A possible role for chromium(III) in genotoxicology. Environ Health Perspect 92:75-81

Sparling D, Linder G, and Bishop C. 2000. Ecotoxicology of Amphibians and Reptiles. SETAC Press, Pensacola, FL, USA

Stewart A. 1999. Accumulation of Cd by a freshwater mussel (Pyganodon grandis) is reduced in the presence of $\mathrm{Cu}, \mathrm{Zn}, \mathrm{Pb}$ and Ni. Can J Fish Aquat Sci 56:467-78 


\section{S. M. Murray et al.}

Sugg DW, Chesser RK, Brooks JA, et al. 1995. The association of DNA damage to concentrations of mercury and radiocesium in largemouth bass. Environ Toxicol Chem 14:661-8

Swihart RK and Slade NA. 1985. Influence of sampling interval on estimates of home-range size. J Wildl Manage 49:1019-25

Tinkle D. 1959. Observations of reptiles and amphibians in a Louisiana swamp. Am Midl Natr 62:189-205

Tsuzuki K, Sugiyama M, and Haramaki N. 1994. DNA single-strand breakage and cytotoxicity induced by chromate(VI), cadium(II), and mercury(II) in hydrogen peroxide-resistant cell lines. Environmental Health Perspectives Supplements 102(53):341-342

USEPA (US Environmental Protection Agency). 1992. Framework for Ecological Risk Assessment. EPA-630-R-93-006. Office of Health and Environmental Assessment, Washington, DC, USA

USEPA. 1993. Wildlife Exposure Factors Handbook, Volume I of II. EPA-600-R-93-187a. Office of Health and Environmental Assessment, Washington, DC, USA

Worton BJ. 1987. A review of models of home range for animal movement. Ecolog Model 38:277-98

Worton BJ. 1989. Kernel methods for estimating the utilization distribution in home-range studies. Ecology 70:164-8

Zar J. 1999. Biostatistical Analysis. Prentice-Hall, Upper Saddle River, NJ, USA 